\title{
An Overview of the Multimedia Environmental Pollutant Assessment System
}

\author{
K. L. Michel \\ Environmental Restoration Division \\ P.O. Box 2003 \\ Oak Ridge, Tennessee 37831.7298
}

Date Issuedmandune 1992

Prepared by

Health and Safety Research Division

Risk Analysis Section

Onk Ridge National Laboratory

Prepared for

U.S. Department of Energy

Office of Environmental Restoration and Waste Management under budget and reporting code EW 20

MARTIN MARIETTA ENERGY SYSTEMS, INC. managing the

Oak Ridge K. 25 site

Oak Ridge Y.12 Plant

Oak Ridge Nutional Laboratory under contract DE-ACO5-840R21400
Paducath Gasseous Diffusion Plant Portsmouth Gaseous Diffusion Plant under contract DE-AC05.760R.000011

for the

U.S. DEPARTMENT OF ENERGY 


\section{Author Affiliations}

\section{K. L. Michel is in Technical Applications in the Computing and Telecommunications Division, Martin Marietta Energy Systems, Inc.}

\section{DISCL,AIMER}

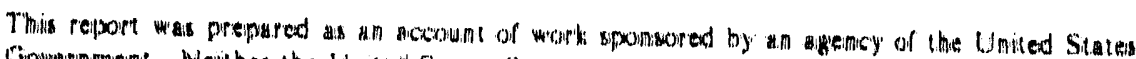

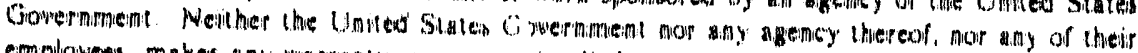

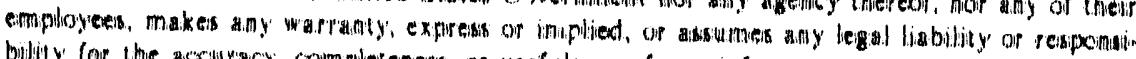

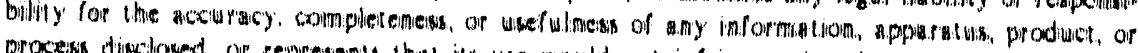

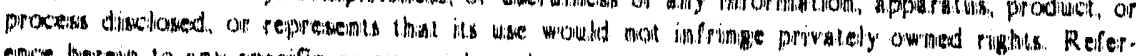

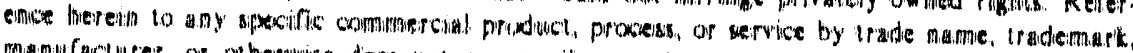

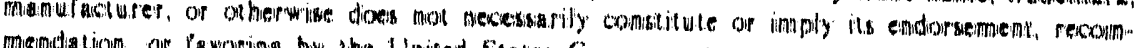

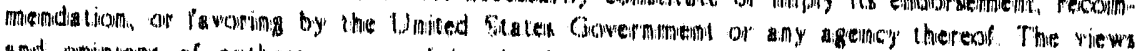

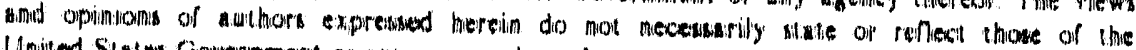
United Sinter Crowermmentit or any agency thereorf. 


\section{CONTENTS}

ABSTRACT $\ldots \ldots \ldots \ldots \ldots \ldots \ldots \ldots \ldots \ldots \ldots \ldots \ldots \ldots \ldots \ldots \ldots \ldots$

1. INTRODUCTION $\ldots \ldots \ldots \ldots \ldots \ldots \ldots \ldots \ldots \ldots \ldots \ldots \ldots \ldots \ldots$

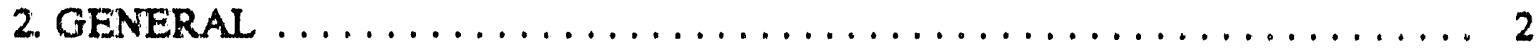

3. CONTAMINANT RELEASES $\ldots \ldots \ldots \ldots \ldots \ldots \ldots \ldots \ldots \ldots \ldots \ldots \ldots$

3.1 RELEASE INTO THE ATMOSPHERE $\ldots \ldots \ldots \ldots \ldots \ldots \ldots \ldots \ldots \ldots$

3.2 RELEASE FROM SOIL $\ldots \ldots \ldots \ldots \ldots \ldots \ldots \ldots \ldots \ldots \ldots \ldots$

3.3 RELEASE TO GROUNDWATER $\ldots \ldots \ldots \ldots \ldots \ldots \ldots \ldots \ldots \ldots \ldots$

3.4 RELEASE TO SURFACE WATER $\ldots \ldots \ldots \ldots \ldots \ldots \ldots \ldots \ldots \ldots \ldots$

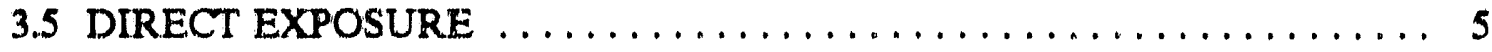

4. EXPOSURE ATHWAYS $\ldots \ldots \ldots \ldots \ldots \ldots \ldots \ldots \ldots \ldots \ldots \ldots \ldots \ldots$

5. HEALTH RIS. 6 INDEXES $\ldots \ldots \ldots \ldots \ldots \ldots \ldots \ldots \ldots \ldots \ldots \ldots \ldots$

5.1 DOSE CALCULATION $\ldots \ldots \ldots \ldots \ldots \ldots \ldots \ldots \ldots \ldots \ldots \ldots \ldots \ldots$

5.2 RISK CALCULATION $\ldots \ldots \ldots \ldots \ldots \ldots \ldots \ldots \ldots \ldots \ldots \ldots \ldots$

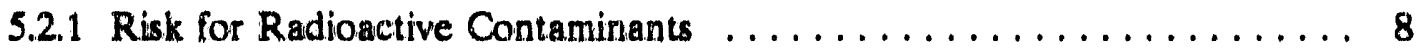

5.2 .2 Risk for Chemical Contaminants .................... 8

5.3 PRELIMINARY HAZARD POTENTLAL INDEX CALCULATION . . . . . 9

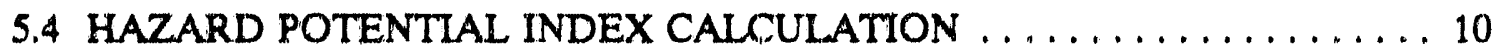

5.5 HAZARD POTENTIAL INDEX SCORE EVALUATION $\ldots \ldots \ldots \ldots \ldots \ldots$

6. EXAMPLE APPLICATION OF MEPAS $\ldots \ldots \ldots \ldots \ldots \ldots \ldots \ldots \ldots \ldots \ldots$

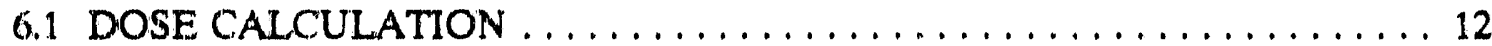

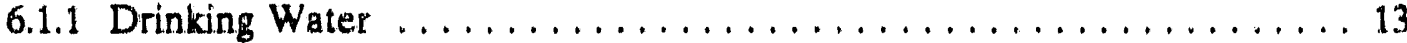

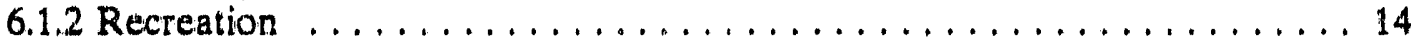

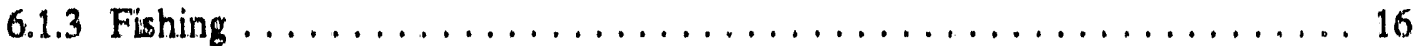

6.2 RISK CALCULATION $\ldots \ldots \ldots \ldots \ldots \ldots \ldots \ldots \ldots \ldots \ldots \ldots \ldots$

6.3 PRELIMINARY HAZARD POTENTIAL INDEX CALCULATION $\ldots \ldots \ldots 18$

6.4 HAZARD POTENTIAL INDEX CALCULATION . . . . . . . . . . . . 19

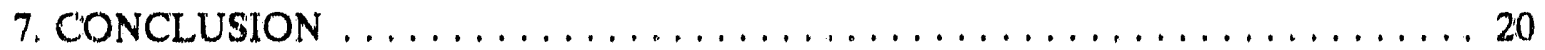

REFERENCES $\ldots \ldots \ldots \ldots \ldots \ldots \ldots \ldots \ldots \ldots \ldots \ldots \ldots \ldots \ldots \ldots \ldots$

APPENDIX A. Input and Output Files Created by MEPAS $\ldots \ldots \ldots \ldots \ldots \ldots \ldots$

APPENDIX B. Example HPI Output File $\ldots \ldots \ldots \ldots \ldots \ldots \ldots \ldots \ldots \ldots \ldots$

APPENDIX C. Example WAT Output File $\ldots \ldots \ldots \ldots \ldots \ldots \ldots \ldots \ldots \ldots$ 


\section{TABLES}

1. Drinking water dose calculation values $\ldots \ldots \ldots \ldots \ldots \ldots \ldots \ldots \ldots \ldots \ldots$

2. Recreation dose calculation values $\ldots \ldots \ldots \ldots \ldots \ldots \ldots \ldots \ldots \ldots \ldots \ldots \ldots$

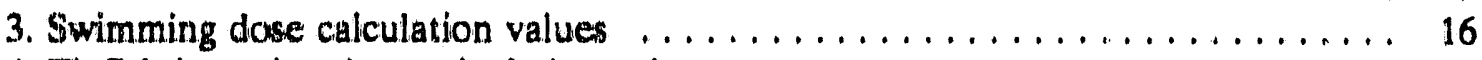

4. Finfish ingestion dose calculation values $\ldots \ldots \ldots \ldots \ldots \ldots \ldots \ldots \ldots \ldots$

5. Risk for ${ }^{137} \mathrm{Cs}$ (radionuclide) $\ldots \ldots \ldots \ldots \ldots \ldots \ldots \ldots \ldots \ldots \ldots \ldots$

6. Risk for polychlorinated biphenyls (chemical carcinogen) . . . . . . . . . 17

7. Risk for mercury (chemical noncarcinogen) $\ldots \ldots \ldots \ldots \ldots \ldots \ldots \ldots \ldots$

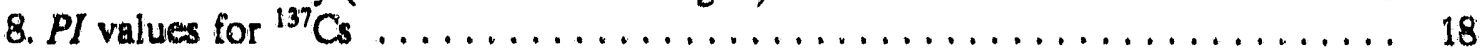

9. PI values for polychlorinated biphenyls $\ldots \ldots \ldots \ldots \ldots \ldots \ldots \ldots \ldots$

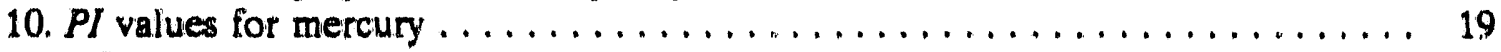

11. HPI scores for example problem $\ldots \ldots \ldots \ldots \ldots \ldots \ldots \ldots \ldots \ldots \ldots$ 


\begin{abstract}
This report describes the Multimedia Environmental Pollutant Assessment System (MEPAS) computer model designed by Pacific Northwest Laboratory for use in evaluating the health risks associated with U.S. Department of Energy (DOE) waste sites. This report has been prepared to provide DOE Oak Ridge Field Office personnel with a simplified explanation of MEPAS and an understanding of how MEPAS is used (t) quantify potential risks to human health. The scope and limitations of the MEPAS model are presented, and the possible contaminant release media and transport pathways are outlined.

The two main types of health indexes generated-the hazard potential index (HPI) and the maximum individual index are described; and calculations used to obtain these indexes are presented. Guidance on interpretation of the $H P I$ is also included. Finally, the HPI calculations for 3 contaminants in a hypothetical environmental problem are demonstrated.

Appendix A contains a list of the input and output files created by MEPAS; Appendix B contains the HPI report for the example problem; and Appendix $\mathrm{C}$ is the WAT output file produced for the eximple problem. This report describes the MEPAS code version $2.1 \mathrm{G}$, dated January 26, 1992, with reports revised April 12,1992. Subsequent versions may contain modifications and enhancements not addressed in this report or values different than those used in the example.
\end{abstract}




\section{INTRODUCTION}

Pacific Northwest Laboratory (PNL) of Richland, Washington, developed the Multimedia Environmental Pollutant Assessment System (MEPAS) computer model for the U.S. Department of Energy (DOE) Office of Environment, Safety, and Health as a tool to evaluate the adverse health impacts of its waste sites and thus rank the sites for cleanup. This report summarizes MEPAS version $2.1 \mathrm{G}$ capabilities and the methodologies used to determine a health-risk-based score for environmental problems. This report has been prepared to provide DOE Oak Ridge Field Office personnel with a simplified explanation of MEPAS and an understanding of how MEPAS is used to quantify potential risks to human health.

The underlying methodology of MEPAS is known as the Remedial Action Priority System (RAPS). This methodology was developed in 1985 and 1986 by PNL with the intent of prioritizing hazardous and radioactive mixed waste disposal sites scientifically and objectively. RAPS and its mathematical formulations (Whelan et al. 1987) have been independently reviewed by technical authorities in the private and public sectors. In addition, the methodology has been tested at facilities where contaminant levels have been monitored in the environment, thus allowing comparison with model-simulated results (Whelan et al. 1989).

MEPAS uses mathematical algorithms to simulate the passage of chemical and radionuclide contaminants through environmental media to specified locations of potential food chain or human exposure. The model then evaluates the degree of exposure that the surrounding population receives and calculates the associated health risk. MEPAS produces two main indicators of risk for each environmental problem modeled: the maxium individual index (MII), based on individual exposure, and the hazard potential index (HPI), weighted by the number of people exposed. Environmental problems can, therefore, be ranked relative to other problems scored by the system.

The model is designed to run on any IBM० personal computer series machine having 640K. RAM, a hard disk, and a printer. A math coprocessor will improve model speed and performance but is not required. 


\section{GENERAL}

MEPAS is designed to be more comprehensive than the site-screening Environmental Protection Agency's (EPA's) Hazard Ranking System and less intensive than risk assessments conducted for remedial investigation/feasibility studies required by the Comprehensive Environmental Response, Compensation, and Liability Act. MEPAS is not intended to determine health risks caused by waste sites precisely but to estimate potential health-risk magnitude. The model does, however, require a considerable amount of data to define the contaminant release, to characterize the transport media, and to define the potential exposure locations and affected populations.

For accurate modeling, a user of MEPAS should have an extensive knowledge of the facility and the surrounding area, including awareness of site meteorology, geology, hydrogeology, soil characteristics, surface water usage, groundwater usage, surrounding population distribution, agriculture production distribution, and history of site activities. In addition, the MEPAS application guidance Volume 2 (Droppo et al. 1989b) supplies itemized, detailed instructions for determining MEPAS inputs, including tables, suggested values and ranges, and possible sources for obtaining required information. It is important that input data be accurate and consistently acquired so that site evaluations and comparisons are credible. 


\section{CONTAMINANT RELEASES}

MEPAS evaluates the potential health risk contributed by individual waste areas within a facility. The source of the contaminant release is referred to in the model as a release unit (RU). For each RU in the facility, the release media, transport pathways, usage locations, and exposure pathways must be defined. Releases can be to air, surface soil (SS), groundwater (GW), or surface water (SW), or the release could be a direct exposure.

The following sections describe each possible contaminant release medium and the pathways through other environmental media which can be modeled. More information about terminology and detining a waste problem to the model can be found in Multimedia Environmental Pollutant Assessment System (MEPAS) Application Guidance-Getting Started with MEPAS (Buck et. al. 1989) and in the MEPAS application guidance Volume 1 (Droppo et. al. 1989a).

\subsection{RELEASE INTO THE ATMOSPHERE}

For a contaminant release to the atmosphere, the following pathways through different environmental media can be modeled.

- Pollutants remain in the air with some deposition to surface soil (RU > Air/SS).

- Pollutants in the air are deposited on the surface soil and are recirculated into the air by volatilization or resuspension (RU $>$ Air $>$ SS $>$ Air/SS) ${ }^{1}$.

- Po. $(\mathrm{RU}>\text { in }>\mathrm{SS}>\mathrm{GW})^{1}$.

- Pollutants in the air are deposited on the soil and leach into groundwater, which discharges into surface water (RU $>$ Air $>$ SS $>$ GW $>$ SW)'.

- Pollutants in the air are deposited on the soil and are washed into surface water via overland runoff $(\mathrm{RU}>\mathrm{Air}>\mathrm{SS}>\mathrm{OL}>\mathrm{SW})^{1}$.

- The air is the source of known pollutants to be used in the exposure evaluation (Air as a source).

To model releases to the air, MEPAS requires local climatological information, including joint frequency distribution, precipitation, and temperature data. Stack, volatilization, and suspension emission rates can be input or MEPAS can compute emission rates for volatilization and suspension based on site-specific data. Population density and agriculture production for up to a 50 -mile radius from the site must be defined two-dimensionally in a matrix of 16 compass directions vs 10 distance intervals.

\footnotetext{
${ }^{1}$ This transport scenario currently involves multiple runs.
} 


\subsection{RELEASE FROM SOIL}

Contaminant release from soil offers transport scenarios similar to those of the atmospheric release. However, the release originates from an area of contaminated surface soil.

- Pollutants on the soil are recirculated into the air by volatilization or resuspension with some deposition back to the soil (SS > Air/SS).

- Pollutants on the soil leach into the groundwater (SS > GW).

- Pollutants on the soil leach into groundwater, which discharges into surface water ( $\mathrm{SS}>\mathrm{GW}>\mathrm{SW}$ ).

- Pollutants on the soil wash into surface water via overland runoff (SS > OL > SW).

MEPAS requires site-specific surface soil characterization information. The user must also define (1) the geometry of the contaminated area, (2) the average concentration of the soil contaminant(s), and (3) the soil type.

\subsection{RELEASE TO GROUNDWATER}

A release to groundwater can be modeled to estimate human exposure in the following ways.

- Pollutants are released into the groundwater and the groundwater is used to affect human exposure via a well or other access method (RU $>\mathrm{GW}$ ).

- Pollutants are released into groundwater that discharges into surface water (RU > GW > SW).

- Groundwater is the source of known pollutants to be used in the exposure evaluation (GW as a source).

Modeling releases into groundwater requires characterizing the different media (partially saturated and saturated zones) through which the waterborne pollutants pass. The user must identify the sand, silt, and clay content of the zone; $\mathrm{pH}$ of the pore water; travel distances in the zone; and thickness, bulk density, total porosity, field capacity, longitudinal dispersion, ar saturated hydraulic conductivity of the zone. Absorption coefficients for each contaminant in each zone can be calculated by MEPAS or be supplied by the user.

Transport pathways involving groundwater generally require longer computer processing time than transport through other media. Peak exposures for this transport media also frequently occur beyond the first 70-year time period. Details on the contaminant distribution are provided in the MEPAS output reports. 


\subsection{REIEASE TO SURFACE WATER}

MEPAS models the following transport scenarios for a contaminant release to surface water.

- Pollutants are released into surface water $(R U>S W)$.

- Surface water is the source of known pollutants to be used in the exposure evaluation (SW as a source).

- Pollutants in surface water are volatilizing into the air (SW as a source $>$ Air) ${ }^{2}$.

- Pollutants in surface water are volatilizing into the air and being deposited on the soil (SW as a source $>$ Air $>$ SS $)^{2}$.

Presently, MEPAS considers only nontidal rivers as surface-water bodies for transport. Surface-water flow is assumed to be unidirectional, steady, and uniform. Users must provide the dimensions of the river receiving contamination, the distance to the closest usage location, and the discharge rate (cubic feet per second) of the river at each usage location.

When contaminants enter surface water from an external discharge source (i.e., groundwater or overland runoff), the contaminant concentration in the river for full distribution is calculated as the contaminant flux entering the river divided by the river's discharge rate. MEPAS also calculates concentrations for pollutants that travel an insufficient distance from source to usage location to become fully mixed with river water. MEPAS accounts for dilution through differences in river discharge rates but currently does not account for contaminant adsorption to and desorption from sediment particles.

\subsection{DIRECT EXPOSURE}

MEPAS models the following direct exposure scenarios:

- Direct soil ingestion

- Measured food concentration ingestion

- Measured radiation dose

To model the direct-exposure pathways, the user must provide the contaminant concentration in soil or food or the measured dose rate of radiation (rads per hour) and an estimate of the number of people exposed. For the measured food concentration ingestion scenario, an average daily intake rate (kilograms per day) for the food product is needed. For direct soil ingestion, the average soil contaminant concentration is used, along with an average life-time ingestion rate of $410 \mathrm{mg} / \mathrm{d}$, to compute risk values.

\footnotetext{
${ }^{2}$ This iransport scenario currently imvolves tiluitiple runs.
} 


\section{EXPOSURE PATHWAYS}

Once the MEFAS user has established the contaminant release media and the transport pathways, the user must define places where humans may be exposed to the destination media. These include groundwater wells, recreation or fishing areas along a river, water intakes for drinking water or irrigation purposes, and inhalation of air and water vapors.

For contamination transported in the atmosphere, MEPAS can simulate exposures to within a 50-mile radius of the site through (1) inhalation of contaminated air and (2) ingestion of agriculture products on which the contaminant has been deposited. The potential routes used for calculating human exposure are listed below.

For exposure to contaminated air/surface soil:

- Air/SS > Inhalation, external exposure, and/or soil ingestion

- Air/SS $>$ Crops >Ingestion

- Air/SS > Crops > Animals >Ingestion

For exposure to contaminated groundwater:

- $\mathrm{GW}>$ Ingestion

- $\mathrm{GW}>$ Bathing > Ingestion/Inhalation

- $G W>$ Irrigation $>$ Crops > Ingestion

- $\mathrm{GW}>$ Irrigation >CCrops > Animals > Ingestion

- $\mathrm{GW}>$ Animals $>$ Ingestion

For exposure to contaminated surface water (SW):

- SW > Ingestion

- $\mathrm{SW}>$ Finfish/Shellfish $>$ Ingestion

- $\mathrm{SW}>$ Irrigation $>$ Ciops $>$ Ingestion

- $\mathrm{SW}>$ Irrigation $>$ Crops $>$ Animals $>$ Ingestion

- $\mathrm{SW}>$ Animals $>$ Ingestion

- SW $>$ Bathing > Ingestion

- $\mathrm{SW}>$ Recreation $>$ External Exposure

- $\mathrm{SW}>$ Recreation > Ingesticn 


\section{HEALTH RISK INDEXES}

MEPAS produces two primary health risk indexes: the MII and the HPI. These are reported in the MEPAS output file with the *.HPI filename (the Hazard Potential Index Report), where * is the user-defined name of the data set used for the run. An example HPI report is given in Appendix B.

The MII is the maxinum individual risk value for radionuclides and carcinogenic chemicals and the maximum individual reference dose ratio for noncarcinogenic chemicals. It is determined from the maximum contaminant dose calculated for an individual or group of equally exposed individuals for each of the exposure scenarios given the receptor placement defined to the model. Exposure media for which the MII is evaluated include inhalation of contaminated air; ingestion of drinking water, fish, vegetables, meat, milk and contaminated soil; and exposure to radiation directly and in contaminated surface water through swimming, boating, and shoreline activities.

The MII is calculated iudependently for each exposure media and route; therefore, the risks or ratios reported are not necessarily common to the same individual but are the highest risks or ratios calculated for contact with a particular contaminant through each independent exposure medium and route. For example, the MII reported for inhalation could be the risk calculated for the person(s) living downwind of and closest to the release site. However, the MII reported for drinking water for the same release unit could be attributed to a different group of people receiving water from an intake nearest a contaminant release to surface water. The MII is calculated according to the risk equations described in Sect. 5.2.

The HPI is an indicator of population risk. It is derived from the cumulative risks to the modeled population and is weighted by the number of people exposed. Its calculation is outlined in this section also.

\subsection{DOSE CALCULATION}

When MEPAS simulates a contaminant's passage through the environmental media selected in the transport scenario, MEPAS calculates a 70 -year average environmental concentration at the locations of potential food-chain or human exposure. This concentration, along with other factors, is used in mathematical equations to determine an individual's average dose for the exposure pathways defined for the usage locations.

A dose from radionuclides is expressed as the effective whole-body dose equivalent received over a 70-year lifetime by an average member of the exposed population (rems per 70 years). For chemicals, the dose is the average daily intake (per unit body weight) that an average member of the exposed population would receive (milligrams per kilograms per day). The average person is assumed to weigh $70 \mathrm{~kg}$.

\section{RISK CALCULATION}

Based on the contaminant type (i.e., radionuclide, carcinogenic chemical, or noncarcinogenic chemical), a risk is calculated for each exposure pathway. 


\section{Rist for Radionctive Contaminants}

The following equation, derived from the BEIR V report (NAS 1990), ws used to estimate a radiation bealth risk:

$$
R_{\mathrm{rad}}=6.3 \mathrm{E}-04 \cdot D c
$$

where

$R_{\text {mat }}$ me thealth risk for exposure to radiation from a specific radionuclide (dimensionlessis), Q.3E $304=$ health effect risk factor (per rem),

$D C=$ MEPAS calculated average individual lifetime diose (rem).

\section{Rist for Cbemical Comtaminants}

For chemical contaminants with carcinogenic propertica, the equation below is used to evaluate the risk:

$$
R_{\mathrm{ct}}=D_{C} \cdot Q
$$

where

$R_{\mathrm{wx}}=$ heaith risk for exposure to a specific chemical carcinogen (dimensioniess),

$D C=$ MEPAS-calculated average daily intake rate of a specific ch emical carcinogen and expowure pathway ( $\mathrm{mg} / \mathrm{kg} / \mathrm{d}$ ),

$Q=$ cancer potency factor for a specific chemical carcinogen $\left[(\mathrm{mg} / \mathrm{kg} / \mathrm{d})^{-1}\right]$.

The reference dose ratio for noncarcinogenic chemicals is evaluated as:

$$
R_{\text {as }}: D \text { S } / R f D
$$

where

$R_{\text {w }}$ peference dose ratio for exposure to a specific chemical noncarcinogen (dimensionless),

Dc mEPAS-calculated average daily intake rate of a specific chemical noncarcinogen and exposure pathway (mg/kg/d),

$R f D=$ reterence dose for a speciffi chemical noncarcinogen ( $\mathrm{ng} / \mathrm{kg} / \mathrm{d}$ ).

Cuncer potency factors and reference dose values are defined in the MEPAS chemical data base (Strenge and Peterson 1989). Thewe values were obtuined primarily from EPA's Inregrated Risk Information System and are updated periodically. Separate values are listed for inhalation and ingestion. To evaluate the risk. MEPAS uses the appropriate value based on the exposure media. 


\section{PRULIMINARY HAZARD POUTENTLAL INDEX CALCUTATION}

Because MEPAS is designed to compare sites that have both carcinogenic and noncarcinogenic chemicials, a relative comparison must be made between cancerous and noncancerous health effects. For a 70 -year lifetime exposure to radionuclides or carcinogenic chemicals, health ris of $10^{-6}$ (one cancer death pitedicted for every one million people exposed) or below is considemed an acceptable level of risk by EPA. Risks higher than 10 (n) (i.e., 10 $0^{-2}$ ) are generally conbidered unacceptable (EPA 1989).

For noncarcinogenic chemicals, the reference dose to which the calculated dowe is compared is the estimated acceptable average daily dose for the specific chemical. Doses larger than the reference dose may cause adverue health effects. Therefore, quotients from noncarcinogenic chemical exposures which are greater than one are considered unacceptable.

The threshold of acceptable risk differs between noncarcinogenic chernical exposures (threshold $=1$ ) and radionuclide and carcinogenic chemical exposures (conservative threshold $\left.=10^{-4}\right)$. MEPAS multiplies risk walues calculated for radioactive contaminames and chemical carcinogens by $10^{6}$ in an attentpt to compare cancer risk with noncapcinogenic reference dose ratio values (Whelan et al. 1987). These converted risk valuet, well as cialculated noncarcinogenic references dose ration, are referred to in the following equations is risk factors.

For each exposure pathway, preliminary hazard potential index (PD) is calculated by multiplying the risk factor by the exposed population.

$$
P I=R F \cdots \cdot \exp (-L t)
$$

where

$P I=$ preliminary hazard potential index for a specilic contaminart and exposure pathway (persons),

$R F=$ risk factor ior the contaminant and exposure pathway (dimensionless),

$P$ number of people exposed (persons),

$L$ time constant for the time-weighting function based on a half-time of "70 years $(0.01 /$ year $)\left(\right.$ year $\left.{ }^{-1}\right)$,

$l$ wime between the beginning of the calculation and the beginning of the current time period (multiples of 70 years).

The PI equation includes a time-weighting factor [exp (mLt)] for exposures extending beyond one 70mear time period for groundwater and surface water scenarios. The atmospheric transport scenarios only deal with the first 70 -year period.

The time factor causes the PI value for each 70-year period to be approximately half of the PI value for the previous 70 -year period; thus, exposures that occur in the distant future are discounted and exposures imposing an imrnediate hazard are given importanci.

The model can be directed to culculate the PI without applying the time-weighting factor to produce an "undiscounted" HPJ for each contaminant. MEPAS also applies the time. weighting factor to the MII and reports both a discounted and undiscounted MII. 


\subsection{HAZAR NOTEMTIAL NDEX CALCULATION}

For en environmental problem area or release unit, $P I$ values for a contaminant are calculated for sach exposure pathway, for each 70-year time period, and for each transport pathway modeled. The sum of these PI values is used in the following equation to determine the HPI for a particular contaminant emitting from the releast. unit:

$$
H P I=10\left(\log _{10} P D\right)
$$

where

$H P I=$ hazard potential index for a particular contaminant from a particular release unit (dimensionless),

$P I=$ the sum of the preliminary hazard potential index values fro all exposure pathways modeled for the contaminant within the release unit (persons).

The HPI score of the release unit's highest-scoring contaminant is considered the hazard potential index for the unit. The PI scores of each modeled contaminant may atso be added together within contaminant type (carcinogen or noncarcinogen) and used in the above equation to obtain a multiple contaminant HPI for the unit ${ }^{3}$. Environmental problem areas can then be ranked by either of these common indexes, according to a population-weighted potential health risk.

\subsection{HAZARD POTENTILAL INDEX SCORE EVALUATION}

HPI values typically range from -250 to 100 . The higher the HPI score, the more serious the calculated population health risk. Because HPI scores are directly related to varying exposure concentrations and populations, guidelines for interpreting HPI values are difficult to establish. The following examples from the MEPAS application guidance Volume 1 (Droppo et al. 1989a) provide a concept of HPI score representation:

- Exposura of one individual at the reference dowe lewel (noncaxcinogen) or cancer potency factor (carcinogen) will give an HPI score of 0 . This is equivalent to a reference dose ratio of one (noncarcinogen) or an individual lifetime risk of $10^{\text {th }}$ (carcinogen).

- Exposure of 1 million people at the reference dose level (noncarcinogen) or cancer potency factor (carcinogen) will give an HPI score of 60 . This is equivalent to a reference dose ratio of one for each of the 1 million people (noncarcinogen) or an individual lifetime risk of $10^{-6}$ for each of the 1 million people (carcinogen).

- Exposure of 10 million people at 10 times the reference dase level (noncarcinogen) or 10 times the cancer potency factol" (carcinogen) will give an HPl score of 80 . "This is rquivatent to a reference dose ratio of 10 for each of the 10 million people

'Because of the logarithmic nature of the HPT, the multiple contaminant HPI will nearly approximate the Hil of the highest scoring comta minant. 
(noncarcinogen) or an individual lifetime risk of $10^{-5}$ for each of the 10 million people (carcinogen).

The preceding examples illustrate the general rule that for each order of magnitude increase in population or exposure dose, the HIPI increases by 10.

The DOE Environment, Safety, and Health Office of Environmental Audit (DOE 1988) categorizes HPI scores as follows:

- Scores 71 to 100

Environmental problems of most concern because of the size of usage populations and the toxicity and concentration of the contaminants.

- Scores 51 to 70

Environmental problems of secondary concern. These scores generally represent large usage populations with moderate concentrations and/or toxicity of contaminants. However, a few problems in this group represent small usage populations where toxicity or concentrations are high.

- Scores 31 to 50

Environmental problems of tertiary concern. These scores are generally a result of small usage populations, low doses, or low-toxicity contaminanis.

- Scores 1 to 30

Environmental problems generally reaching usage locations at levels well below those used in regulatory decisions.

- Scores 0 or below

Environmental problems not projected to reach usage locations.

Another way to examine the HPI is to use the index to calculate the total cancer fatalities predicted to occur as a result of the environmental problem modeled. To do this, the HPI is converted back to the PI: PI $=10^{\mathrm{kPt} / \mathrm{No}}$. The $P I$ is then multiplied by $10^{-6}$ to remove the $10^{6}$ factor used to normalize carcinogenic risks to reference dose ratios (see Sect. 5.3). This leaves the predicted number of cancer fatalities (cancer risk times the exposed population) for each exposure pathway, 70-year time period, and transport pathway included in the HPI calculation. "The simplified equation is:

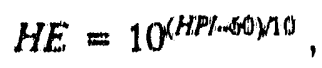

where $H E=$ number of cancer fatalities expected over the lifetime of the environmental problem (persons).

This calculation can only be applied to the HPI numbers for radionuclides and carcinogenic chemicals. It has little mernang for noncarcinogenic chemicals because the reference dose ratio is not a measure of rivik but a comparison between the dose received and the acceptable dowe. The population is either getting less than, more than, or the same dose as the reference dose. 


\section{EXAMPLE APPLICATION OF MEPAS}

In this chapter, MEPAS calculations will be applied to the following hypothetical environmental problem to illustrate the methodology MEPAS uses in assigning an HPI. The *.HPI and *.WAT MEPAS output files for this example are presented in Appendix B and Appendix C, respectively.

An industry is releasing ${ }^{137} \mathrm{Cs}$ (at $0.57 \mathrm{Ci} / \mathrm{year}$ ), polychlorinated biphenyls (PCBs) (at $4200 \mathrm{~g} / \mathrm{year}$ ), and mercury (at $672 \mathrm{~g} / \mathrm{year}$ ) into a stream that flows into a river. These releases are expected to continue at the same rate for $\mathbf{4 0}$ years. An intake that draws, treats, and distributes river water for domestic use is located along the river. The river is also used for recreation: shoreline activities, swimming, and boating. The population eats finfish from the river. It is assumed that the river contains approximately the same volume of water at each of the usage locations.

\subsection{DOSE CALCULATION}

Using input data describing the release, transport pathway, and environmental media, MEPAS simulates contaminant transport to the usage locations modeled. The 70-year average concentration in the surface water is then calculated for each contaminant at these usage locations. The 70-year average contaminant concentrations in water ate found in the MEPAS output file with a *.WAT filename, where "is the user-defined name of the data set used for the run. The concentrations are in the next-to-last column and are in units of atto $\left(10^{-18}\right)$ curies per milliliter or atto grams per milliliter. These units must be converted to pico curies per liter or milligrams per liter for use in the following dose calculations. A set of concentrations is given for each usage location.

The concentration values in the *.WAT file do not account for decay or degradation of contaminants which occurs in transit from the source to the usage location. MEPAS version $2.1 \mathrm{G}$ includes the following equation to more accurately estimate contarninant concentrations at the usage location:

$$
C w=C a * \exp \left(-\lambda w^{*} t t\right)
$$

where

$C w=$ average water concentration of the contaminant after decay or degradation $(\mathrm{mg} / \mathrm{L}$ or $\mathrm{pCi} / \mathrm{L}$ )

$\mathrm{Ca}=$ average water concentration of the contaminant obtained from the ".WAT file $(\mathrm{mg} / \mathrm{L}$ or $\mathrm{pCi} / \mathrm{L})$

$\lambda w=$ environmental degradation or radiological decay constant for the contaminant in surface water $\left(\mathrm{d}^{-1}\right)$

$t t=$ contaminant travel time from source to usage location (d)

The decay constant for the contaminant in surface water $(\lambda w)$ is computed as: 


$$
\lambda w=(\ln 2) / t,
$$

where $t=$ the contaminant environmental hali-life in surface water listed in the MEPAS chemical data base in days. The contartinant travel time is computed as the distance to the first usage location divided by the velocity of the surface water. In this example, the first usage location is $8000 \mathrm{ft}$ from the source and the veloxity of the river is $0.8 \mathrm{ft} / \mathrm{sec}$. The contaminant travel time is 10,000 seconds or 0.116 days.

\subsubsection{Drinking Water}

MEPAS wes the following equation to calculate the dose an average individual would receive by ingesting drinking water from a contaminated source:

$$
D_{w}=U_{W} * C_{W} * T f * D_{g} * \exp \left(-\lambda_{w} " t p\right),
$$

where

$D_{w}=$ average individual dose for a specific contaminant from ingesting drinking water (mg/kg/d or $\mathrm{rem} / 70$ years),

$U_{W}=$ average daily water intake rate for an individual (L/d),

$\mathrm{Cw}=$ average water concentration of the contaminant (mg $/ \mathrm{L}$ or $\mathrm{pCi} / \mathrm{L})$,

Tf = water purification factor, fraction of contaminant remaining after treatment (dimensionless).

$D_{\mathrm{g}}=$ ingestion dose conversion factor for the contaminant $\left(\mathrm{kg}^{-1}\right.$ or rem/pCi),

$\lambda w=$ environmental degradation or radiological decay constant for the contaminant in surface water $\left(d^{-1}\right)$,

$t p=$ average time of transit through the water distribution system (day).

As the average rate of daily water intake ( $\left.U_{w}\right)$, MEPAS uses $2 \mathrm{~L} / \mathrm{d}$ for drinking water plus $0.01 \mathrm{~L} / \mathrm{d}$ ingested from domestic bathing. For radionuclides such as ${ }^{137} \mathrm{Cs}$, the amourt of water ingested over a 70 -year period $(5.14 \mathrm{E}+04$ liters $)$ must be used. The contaminant concentration in the water at the intake $(\mathrm{Cw})$ can be obtained from the ". WAT output file and refined as described above.

The MEPAS chemiral data base contains the water treatment purification factor (TR) for each contaminant. It is the estirnated percentage of the contaminant that remains following common water treatment processing. If the water is not treated before drinking, all contaminants will have a purification factor of one.

The ingestion dose conversion factor $\left(D_{\mathrm{g}}\right)$ for chemical contaminants is $1770 \mathrm{~kg}$ to relate dose to unit body weight of an average adult. For radicnuclides, $D g$ is the ingestion dose factor in the MEPAS chemical data base. The decay constant for the contaminant in surface water $(\lambda w)$ is computed as shown above. The MEPAS default value of $0.5 d$ for the average time of transit through the water distribution system (tp) will be used in this example.

Table 1 shows the values of variables and the average individual dose from drinking water ingestion for each of the contaminants considered in this exampie. 
Table 1. Drinking water doece calculation values

\begin{tabular}{|c|c|c|c|c|c|}
\hline Contaminant & Cw & $T f^{\prime}$ & $D g$ & $\lambda w\left(d^{-1}\right)$ & Dose $(D w)$ \\
\hline Cesium-137 & 7.40E-02 pCi $/ \mathrm{L}$ & 0.9 & $5.0 \mathrm{E}-08 \mathrm{rem} / \mathrm{pCl}$ & $6.3 E-05$ & $\begin{array}{l}1.71 \mathrm{E}-04 \mathrm{rem} / \\
70 \text { year }\end{array}$ \\
\hline PCB & $4.10 \mathrm{E}-07 \mathrm{mg} / \mathrm{L}$ & 0.1 & $1.43 E-02 \mathrm{~kg}^{-1}$ & 247E0 & $3.42 \mathrm{E}-10 \mathrm{mg} / \mathrm{kg} / \mathrm{d}$ \\
\hline Mercury & $8.73 E-08 \mathrm{mg} / \mathrm{L}$ & 0.5 & $1.43 \mathrm{E}-0.2 \mathrm{~kg}^{-1}$ & $1.0 \mathrm{E}-08$ & $1.25 \mathrm{E}-09 \mathrm{mg} / \mathrm{kg} / \mathrm{d}$ \\
\hline
\end{tabular}

\section{1 .2 Recreation}

Exposure from surface-water contaminants in recreational areas is attributed primarily to radionuclides. The following equation combines calculated radionuclide exposures during boating, swimming, and shoreline activities.

$$
D e=70 *(0.5 * t b+t s) * C w * D b+70 * t f * C d * W * D s,
$$

where

De $=$ radiation dose to an individual from external exposure to a specific radionuclide (rem/70 year),

$t b=$ average time spent by an individual boating (h/year),

ts $=$ average time spent by an individual swimming (h/year),

$\mathrm{C} w=$ average water concentration of the contaminant $(\mathrm{pC} / \mathrm{L})$;

$D b=$ external dose conversion factor for the radionuclide for immersion in water (rem*L/pCi*h),

tf $=$ average time spent by an individual in shoreline activities (h/year),

$C d=$ average sediment concentration of the contaminant deposited on the, shoreline from contaminated water $\left(\mathrm{pCi} / \mathrm{m}^{2}\right)$,

$W=$ shore-width factor to correct for finite size of shoreline (dimensionless),

$D s=$ external dose conversion factor for exposure to a contaminated plane (soil exposure factor) of the radionuclide (rem" $\left.\mathrm{m}^{2} / \mathrm{pCi} * \mathrm{~h}\right)$.

The average individual is estimated to spend $12 \mathrm{~h} / \mathrm{year}$ in each of the three activities considered $(t b, t s$, and $t)$. The boating exposure time is reduced by half $\left(0.5^{*}(b)\right.$, because only partial immersion in water is experienced. The MEPAS chemical data base contains dose conversion factors for immersion in water $(D b)$ and exposure to contaminated soil $(D s)$. MEPAS uses 0.2 as the shore width factor $(W)$ derived from experimental data (Dunster 1971). The average contaminant concentration in shoreline sediments $(C d)$ is estimated using the following equation (Soldat et al. 1974):

$$
C d=100 * t * C_{w} *[1-\exp (-\lambda s * t w)]
$$


where

$C d=$ average sediment concentration of the contaminant deposited on the shoreline from contaminated water $\left(\mathrm{pCi} / \mathrm{m}^{2}\right)$,

$100=$ transfer constant from water to sediment $\left(\mathrm{L} / \mathrm{m}^{2} / \mathrm{d}\right)$,

$t=$ physical half-life of the radionuclide (d),

$\mathrm{C} w=$ average water concentration of the contaminant $(\mathrm{pCi} / \mathrm{L})$,

$\lambda s=$ radiological decay constant for the contaminant in soil $\left(\mathrm{d}^{-1}\right)$,

$t w$ = length of time the shoreline sediment is exposed to the contaminated water.

The MEPAS chemical data base contains the physical half-life of the radionuclide $(t)$. The radiological decay constant $(\lambda s)$ is calculated as discussed for the drinking water dose, using the value for the half-life in soil instead of surface water. The length of time the shoreline sediment is exposed to the contaminated water $\left(t w^{\prime}\right)$ is estimated at half the 70-year evaluation period or 12,780 days.

Table 2 shows the values of variables and the calculated average individual exposure dose from swimming, boating, and shoreline activities in and around contaminated surface-water recreational areas.

Table 2 Recreation dose calculation values

\begin{tabular}{cccccc}
\hline Contaminant & $C w$ & $D b$ & $C d$ & $D s$ & Dose (De) \\
\hline Cesium-137 & $\begin{array}{c}7.40 \mathrm{E}-02 \\
\mathrm{pCi} / \mathrm{L}\end{array}$ & $\begin{array}{c}6.9 \mathrm{E}-10 \\
\mathrm{rem} \mathrm{Lm}_{\mathrm{pCi}} * \mathrm{~h}\end{array}$ & $\begin{array}{c}4.50 \mathrm{E}+04 \\
\mathrm{pCi} / \mathrm{m}^{2}\end{array}$ & $\begin{array}{c}6.8 \mathrm{E}-12 \\
\mathrm{rem} \mathrm{m}^{2} / \mathrm{pCi} \mathrm{Ci}^{*} \mathrm{~h}\end{array}$ & $\begin{array}{c}5.15 \mathrm{E}-05 \\
\mathrm{rem} / 70 \text { year }\end{array}$ \\
\hline
\end{tabular}

MEPAS also calculates the dose an individual would receive by inadvertently ingesting water while swimming. Unlike the previously calculated doses for the recreation pathway, this dose is calculated for nonradionuciides as well as radionuclides. The following equation is used:

$$
\operatorname{Dr}=0.10 * C w * t s * D g / 365
$$

wher:

$\mathrm{Dr}=$ average dose of a particular contaminant an individual receives by inadvertently ingesting water while swimming ( $\mathrm{mg} / \mathrm{kg} / \mathrm{d}$ or rem/70 years),

$0.10=$ inadvertent water ingestion rate during recreational swimming $(\mathrm{L} / \mathrm{h})$,

$C_{w}=$ average water concentration of the contaminant $(\mathrm{mg} / \mathrm{L}$ or $\mathrm{pCi} / \mathrm{L})$,

$i s=$ average time an individual spends swimming (12 $\mathrm{k} / \mathrm{year})$,

$D_{g}=$ ingesticn dose conversion factor for the contaminant $\left(\mathrm{kg}^{-1}\right.$ or rem/pCi),

$365=$ days per year.

Table 3 shows the calculated values of variables and doses applicable to ingestion of contaminated water while swimming. 
Tables 3. Swirmming dose calculation values

\begin{tabular}{llll}
\hline Contaminant & \multicolumn{1}{c}{$C w$} & \multicolumn{1}{c}{ Dg } & \multicolumn{1}{c}{ Dose $(D r)$} \\
\hline Cesium-137 & $7.40 \mathrm{E}-02 \mathrm{pCi} / \mathrm{L}$ & $5.0 \mathrm{E}-08 \mathrm{rem} / \mathrm{pCi}$ & $3.12 \mathrm{E}-07 \mathrm{rem} / 70$ year \\
PCBs & $4.10 \mathrm{E}-07 \mathrm{mg} / \mathrm{L}$ & $1.43 \mathrm{E}-02 \mathrm{~kg}^{-1}$ & $1.93 \mathrm{E}-11 \mathrm{mg} / \mathrm{kg} / \mathrm{d}$ \\
Mercury & $8.73 \mathrm{E}-08 \mathrm{mg} / \mathrm{L}$ & $1.43 \mathrm{E}-02 \mathrm{~kg}^{-1}$ & $4.10 \mathrm{E}-12 \mathrm{mg} / \mathrm{kg} / \mathrm{d}$ \\
\hline
\end{tabular}

\subsubsection{Fishing}

River contaminants enter the food chain and affect the population when people eat finfish caught from the river. MEPAS uses the following equation to calculate the average individual dose from ingestion of finfish:

$$
D f=U f * C w * B f * D g * \exp (-\lambda w * t f)
$$

where

$D f=$ average individual dose from ingesting finfish for a particular contaminant $(\mathrm{mg} / \mathrm{kg} / \mathrm{d}$ or rem/70 year),

$U f=$ average individual consumption rate of finfish $(\mathrm{kg} / \mathrm{d})$,

$C w=$ average water concentration of the contaminant $(\mathrm{mg} / \mathrm{L}$ or $\mathrm{pCi} / \mathrm{L})$,

$B f=$ bioaccumulation factor for finfish and the specific contaminant ( $\mathrm{L} / \mathrm{kg}$ ),

$D_{g}=$ ingestion dose ronversion factor for the contaminant $\left(\mathrm{kg}^{-1}\right.$ or rem/pCi),

$\lambda w=$ environmental degradation or radiological decay constant for the contaminant in surface water $\left(d^{-1}\right)$,

if = average time for decay from food harvest to consumption (d).

The average individual consumption rate for finfish is estirnated as $0.0065 \mathrm{~kg} / \mathrm{d}$. To calculate radionuclide exposure, the amount of finfish the average individual ingests over a 70-year period $(1.66 \mathrm{E}+02 \mathrm{~kg})$ must be used. For each constituent, the MEPAS chemical data base defines the bioaccumulation factors used for finfish and other food sources. The MEPAS default values for the average decay tirne from food harvest to consumption $(t), 0.5 \mathrm{~d}$, will be used in this example.

Table 4 gives the values of variables and the average dose an individual receives from ingesting finfish for each of the contarninants considered in this example. 
Table 4. Finfish ingestion dose calculation values

\begin{tabular}{lccc}
\hline Contaminant & $C w$ & $B f(\mathrm{~L} / \mathrm{kg})$ & Dose $(D f)$ \\
\hline Cesium-137 & $7.40 \mathrm{E}-02 \mathrm{pCi} / \mathrm{L}$ & $2.0 \mathrm{E}+03$ & $1.23 \mathrm{E}-03 \mathrm{rem} / 70 \mathrm{year}$ \\
PCBs & $4.10 \mathrm{E}-07 \mathrm{mg} / \mathrm{L}$ & $1.8 \mathrm{E}+05$ & $1.99 \mathrm{E}-06 \mathrm{mg} / \mathrm{kg} / \mathrm{d}$ \\
Mercury & $8.73 \mathrm{E}-08 \mathrm{mg} / \mathrm{L}$ & $2.0 \mathrm{E}+05$ & $1.62 \mathrm{E}-06 \mathrm{mg} / \mathrm{kg} / \mathrm{d}$ \\
\hline
\end{tabular}

\section{RISK CALCULATION}

Using the doses for each potential exposure, the risk and reference dose ratio can be calculated by the formulas discussed in Sect. 4 . Because this example has only one usage location for each exposure to drinking water, recreational activities, and finfish and each location considers a population of equally exposed individuals, these risk and reference dose ratio values are also reported by MEPAS as the MIIs for each contaminant and exposure. Tables 5, 6, and 7 show the risk for each contaminant and exposure in this example calculation.

Table 5. Risk for ${ }^{27} \mathrm{Cs}$ (radionuclide)

\begin{tabular}{lcc}
\hline \multicolumn{1}{c}{ Exposure } & Dose (rem $/ 70$ year) & Risk \\
\hline Drinking water & $1.71 \mathrm{E}-04$ & $1.08 \mathrm{E}-07$ \\
Recreation & $5.15 \mathrm{E}-05$ & $3.24 \mathrm{E}-08$ \\
Swimming & $3.12 \mathrm{E}-07$ & $1.96 \mathrm{E}-10$ \\
Finfish & $1.23 \mathrm{E}-03$ & $7.74 \mathrm{E}-07$ \\
\hline
\end{tabular}

Table 6. Risk for polychlorinated biphenyls (chemical carcinogen)

\begin{tabular}{lccc}
\hline \multicolumn{1}{c}{ Exposure } & Dose $(\mathrm{mg} / \mathrm{kg} / \mathrm{d})$ & $\begin{array}{c}\text { Cancer potency factor } \\
{\left[(\mathrm{m} / \mathrm{kg} / \mathrm{d})^{-1}\right]}\end{array}$ & Risk \\
\hline Drinking water & $3.42 \mathrm{E}-10$ & 7.7 & $2.64 \mathrm{E}-09$ \\
Swimming & $1.93 \mathrm{E}-11$ & 7.7 & $1.48 \mathrm{E}-10$ \\
Finfish & $1.99 \mathrm{E}-06$ & 7.7 & $1.54 \mathrm{E}-05$ \\
\hline
\end{tabular}


Table 7. Rist for mercury (chemical noncarcinogen)

\begin{tabular}{lccc}
\hline \multicolumn{1}{c}{ Exposure } & $\begin{array}{c}\text { Dose } \\
(\mathrm{mg} / \mathrm{kg} / \mathrm{d})\end{array}$ & $\begin{array}{c}\text { Reference dose } \\
(\mathrm{mg} / \mathrm{kg} / \mathrm{d})\end{array}$ & $\begin{array}{c}\text { Reference } \\
\text { dose ratio }\end{array}$ \\
\hline Drinking water & $1.25 \mathrm{E}-09$ & $3.0 \mathrm{E}-04$ & $4.18 \mathrm{E}-06$ \\
Swimming & $4.10 \mathrm{E}-12$ & $3.0 \mathrm{E}-04$ & $1.37 \mathrm{E}-08$ \\
Finfish & $1.62 \mathrm{E}-66$ & $3.0 \mathrm{E}-04$ & $5.41 \mathrm{E}-03$ \\
\hline
\end{tabular}

\subsection{PREILIMTNARY HAZARD POTENTIAL INDEX CAICULATION}

After multiplying the risk values calculated for the radionuclide and carcinogenic chemicals $\left({ }^{137} \mathrm{Cs}\right.$ and PCBs) by $10^{6}$ (see Sect. 5.3), the risk factors can be multiplied by the population present at each exposure and then totaled for each contaminant to determine the $P I$. The population using water from the intake is estimated to be 2000 people. One hundred eighiy thousand people are estimated to use the recreational area of the river. An estimated $10,000 \mathrm{~kg}$ of finfish are consumed from the river each year. The number of people affected by this food source is computed as follows:

$$
P f=P d /\left(I r^{* 365)}\right. \text {, }
$$

where

$$
\begin{aligned}
& P f=\text { population affected by the food source, } \\
& P d=\text { production rate of food source (kg/year or L/year), } \\
& I r=\text { average individual ingestion rate of food source }(\mathrm{kg} / \mathrm{d} \text { or } \mathrm{L} / \mathrm{d}), \\
& 365 \text { = days per year. }
\end{aligned}
$$

MEPAS estimates that the average individual ingests $0.0065 \mathrm{~kg} / \mathrm{d}$ of finfish each year. An estimated $\mathbf{4 2 1 5}$ people are calculated as being exposed to contaminated finfish from the river. Tables 8, 9, and 10 show PI calculations for each contaminant.

Table 8. PI values for ${ }^{157} \mathrm{C}$

\begin{tabular}{lrrr}
\hline \multicolumn{1}{c}{ Exposure } & Risk factor & Population & \multicolumn{1}{c}{$P I$} \\
\hline Drinking water & $1.08 \mathrm{E}-01$ & 2000 & $2.16 \mathrm{E}+02$ \\
Recreation & $3.24 \mathrm{E}-02$ & 180,000 & $5.83 \mathrm{E}+03$ \\
Swimming & $1.96 \mathrm{E}-04$ & 180,000 & $3.53 \mathrm{E}+01$ \\
Finfish & $7.74 \mathrm{E}-01$ & 4215 & $3.26 \mathrm{E}+03$ \\
$\quad$ & & & $9.34 \mathrm{E}+03$ \\
\hline
\end{tabular}


Table 9. PI values for polychlorinated biphenyls

\begin{tabular}{lrrr}
\multicolumn{1}{c}{ Exposure } & Risk factor & Population & \multicolumn{1}{c}{$P I$} \\
\hline Drinking water & $2.64 \mathrm{E}-03$ & 2000 & $5.28 \mathrm{E} 0$ \\
Swimming & $1.48 \mathrm{E}-04$ & 180,000 & $2.66 \mathrm{E}+01$ \\
Finfish & $1.54 \mathrm{E}+01$ & 4215 & $6.49 \mathrm{E}+04$ \\
$\quad$ & & $6.49 \mathrm{E}+04$ \\
\hline
\end{tabular}

Table 10. PI vialues for mencury

\begin{tabular}{lrrr}
\hline \multicolumn{1}{c}{ Exposure } & Risk factor & Population & \multicolumn{1}{c}{$P I$} \\
\hline Drinking water & $4.18 \mathrm{E}-06$ & 2000 & $8.36 \mathrm{E}-03$ \\
Swimming & $1.37 \mathrm{E}-08$ & 180,000 & $2.47 \mathrm{E}-03$ \\
Finfish & $5.41 \mathrm{E}-03$ & 4215 & $2.28 \mathrm{E}+01$ \\
$\quad$ & & & $2.28 \mathrm{E}+01$ \\
\hline
\end{tabular}

\subsection{HAZARD POTENTIAL, INDEX CALCULATION}

The HPI is calculated as described in Sect. 5.4 using the total $P I$ value. Table 11 shows the HPI scores for each contaminant modeled in this example.

Table 11. HPI scores for example problem

\begin{tabular}{lcc}
\hline Contaminant & PI & HPI \\
\hline Cesium-137 & $9.34 \mathrm{E}+03$ & 39.7 \\
PCBs & $6.49 \mathrm{E}+04$ & 48.1 \\
Mercury & $2.28 \mathrm{E}+01$ & 13.6 \\
\hline
\end{tabular}

The highest HPI score is the PCB score of 48.1, resulting primarily from ingestion of finfish. This score is considered to be the HPI of the example environmental problem for the surface-water transport pathway. 


\section{CONCLUSION}

MEPAS is a complex pollutant simulation model that requires experience in personal computer operations and an extensive knowledge of the conditions surrounding the environmental problems modeled. Although this report does not attempt to analyze the MEPAS code in detail, the calculations and methods used to simulate contaminant transport and evaluate contaminated sites are adequate.

Contaminant releases can be modeled to the atmosphere, surface soil, groundwater, and surface water. MEPAS can simulate contaminant transport through multiple er vironmental media to potential human exposure locations. Dire $: t$ ingestion of contaminated soil, ingestion of a measured contaminant concentration in food, and measured direct radiation can also be simulated.

MEPAS evaluates the health risk of the average person using average inhalation and consumption rates for a 70-year lifetime. The MII, showing individual risk, and the HPI, measuring population risk, are produced as indicators of potential human health risk. 


\section{REFERENCES}

Buck, J. W. et al. December 1989. Multimedia Environmental Pollutant Assessment System (MEPAS) Application Guidance-Getting Started with MEPAS, PNL-7136, Pacific Northwest Laboratory, Richland, Washington.

DOE. September 1988. Environmental Survey Preliminary Summary Report of the Defense Production Facilities, DOE/EH-0072, Washington, D.C.

Droppo, J. G., Jr. et al. December 1989a. Multimedia Environmental Pollutant Assessment System $\left(M E P A S^{\bullet}\right)$ Application Guidance. Volume 1-User's Guide, PNL-7216-Vol. 1, Pacific Northwest Laboratory, Richland, Washington.

Droppo, J. G., Jr. et al. December 1989b. Multimedia Environmental Pollutant Assessment System (MEPAS) Application Guidance. Volume 2-Guidelines for Evaluating MEPAS Input Parameters, PNL 7216. Vol. 2, Pacific Northwest Laboratory, Richland, Washington

Dunster, H. J. (chairman). 1971. Handbook of Radiological Protection Part 1: Data, SNB $11=360079-8$, Radioactivity Advisory Committee, Department of Employment, Department of Health and Social Security, Ministry of Health and Social Services, Northern Ireland; Her Majesty's Stationery Office, London,

EPA. 1982. Health Effects Assessment Summary for 300 Hazardous Onganic Constituents, Environmental Criteria and Assessment Office, U.S. Environmental Protection Agency, Cincinnati, Ohio.

EPA. 1989. Risk Assessment Guidance for Superfund. Volume 1. Human Health Evaluation Manual Part A, U. S. Environmental Protection Agency, Cincinnati, Ohio.

NAS (National Academy of Sciences). 1990. Health Effects of Exposure to Lory Levels of Ionizing Radiation: BEIR V. National Academy of Sciences Committee on the Effects of Ionizing Radiations, National Research Council, Washington, D.C.

Soldat, J. K., N. M. Robinson, and D. A. Baker. 1974. Models and Computer Codes for Evaluating Environmental Radiation Doses, BNWL-1754, Pacific Northwest Laboratory, Richland, Washington.

Strenge, D. L. and S. R. Peterson. September 1989. Chemical Data Bases for the Multimedia Environmenu'l Pollutant Assessment System (MEPAS): Version 1, Pacific Northwest Laboratory, Richland, Washington.

Whelan, G. et al. December 1989. A Demonstration of the Applicability of Implementing the Enhanced Remedial Action Priority System (RAPS) for Environmental Releases, Pacific Northwest Laboratory, Richland, Washington.

Whelan, G. et al. August 1987. The Remedial Action Priority System (RAPS): Mathematical Formulations, DOE/RL-87-09, PNL6200, Pacific Northwest Laboratory, Richland, Washington. 
Appendix A

INPUT AND OUTTUT FLES CREATED BY MTEPAS 


\section{Input and Output Files Created by MEPAS}

Input Files Created by MEPAS

\begin{tabular}{lll}
\hline File name & Component & File contents \\
\hline *BAT & Generic & Batch command file \\
-DET & Atmospheric & Contaminant data file used by the volatilization component \\
.HIN & Exposure & Usage location input \\
".ID & Generic & Control file containing the names of files to be run \\
.JFD & Atmospheric & Joint frequency distribution used in worksheet 3.2 \\
.MET & Atmospheric & Meteorology input \\
-POP & Atmospheric & Fopulation distribution used in worksheet 4.3 \\
-SOU & Atmospheric & Source-term input \\
-TOP & Atmospheric & Topography and surface roughness \\
"WIN & Waterborne & Source-term and environmental input \\
\hline
\end{tabular}

- Represents the user-defined name of the data set used for the run. 
Input and Output Files Created by MEPAS

Output Files Created by MEPAS

\begin{tabular}{|c|c|c|}
\hline File name & Component & File contents \\
\hline${ }^{*}$.AIR & Atmospheric & $\begin{array}{l}\text { 70-year average air concentration used as input to the exposure } \\
\text { component }\end{array}$ \\
\hline *ALC & Atmospheric & Intermediate mass budget data \\
\hline .Als & Atmospheric & Intermediate meteorological, emission, and dispersion data \\
\hline. $\mathrm{CNC}$ & Atmospheric & Contaminant concentrations used by the exposure component \\
\hline *.HPI & Exposure & Final report showing computed HPI and MII values \\
\hline$\because$ POL & Waterborne & $\begin{array}{l}\text { Intermediate results of detailed pollutograph (concentration } \\
\text { versus time) }\end{array}$ \\
\hline *.RSK & Exposure & $\begin{array}{l}\text { Intermediate HPI results used to produce the HPI summary } \\
\text { report (".THP) }\end{array}$ \\
\hline .THP & Exposure & $\begin{array}{l}\text { Final summary report combining HPIs for different runs within } \\
\text { the same hierarchical unit }\end{array}$ \\
\hline *VOL & Atmospheric & $\begin{array}{l}\text { Volatilization emission rates }(\mathrm{g} / \mathrm{s}) \text { used by the exposure } \\
\text { component }\end{array}$ \\
\hline. WAT & Waterborne & $\begin{array}{l}\text { 70-year average water concentrations used as input to the } \\
\text { exposure component }\end{array}$ \\
\hline *WLS & Waterborne & $\begin{array}{l}\text { Intermediate processed input and calculated data, peak } \\
\text { concentrations and time of arrival for each contaminant }\end{array}$ \\
\hline
\end{tabular}

Represents the user-defined name of the data set used for the run. 
Appendir B

EXAMPLE HPI OUTPUT FILE 


\section{Example HPI Output File}

Multimedia Environmental Pollutant ABgesement syotom (MEPAS)

MEPAS Hazard Potential Output (VERSION 041292)

Pacific Northwest Laboratory

Richland, Wh 99352

Developed for the U.S. Department of Bnergy

Run Date and Time: 4/14/1992 16:2:32

(Thia run uged 630. offect per milition man-rem)

Run Title: Bxample kanking Unit

Ranking Unit 1 : EXAKPLE

Number of Constituent is: 3

Time Discounted HPI are computed using 70 year time periods (Time Index = 0 )

Nurn Constituent Names

CAEID

1 CESIUM $-137+D$

CS137

2 Mercury, Quicksilvar

7439976

3 Aroclor, PCB (General Clageification), Therminal

1336363 
Example HPI Output File

CoMB Sumary of Data From MBPAs conetituent Databage 1991

Th1: Database Contains Entries for 397 constituents

\begin{tabular}{|c|c|c|c|c|}
\hline & $\begin{array}{l}\text { arameter } \\
\text { Unita }\end{array}$ & int $\frac{1}{d}$ & $\frac{1 \text { et } 1 \text { tuent }}{2}$ & notituer \\
\hline 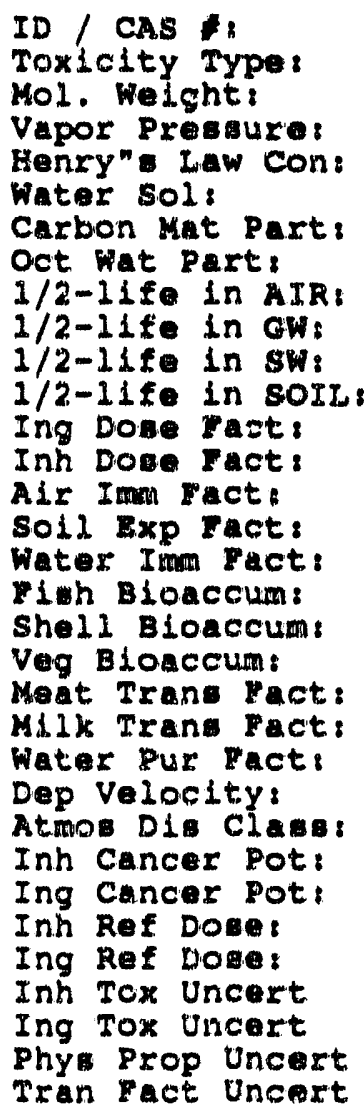 & 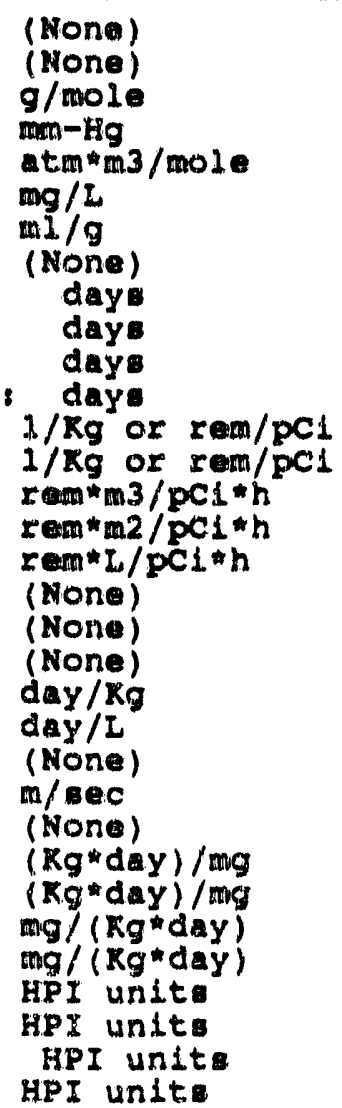 & 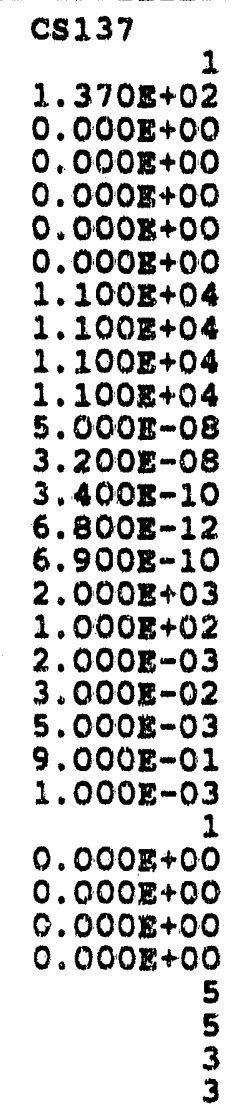 & $\begin{array}{l}74.39976 \\
2.010 z+0 \\
2.000 z-0 \\
1.140 z-0 \\
3.000 z-0 \\
0.000 z+0 \\
0.000 z+0 \\
6.900 z+0 \\
6.900 z+0 \\
6.900 z+0 \\
6.900 z+0 \\
1.430 z-0 \\
1.430 z-0 \\
0.000 z+0 \\
0.000 z+0 \\
0.000 z+0 \\
2.000 z+0 \\
2.000 z+0 \\
3.800 z-0 \\
1.000 z-0 \\
1.900 z-0 \\
5.000 z-0 \\
1.000 z-0 \\
0.000 z+0 \\
0.000 z+0 \\
3.000 z-0 \\
3.000 z-0\end{array}$ & $\begin{array}{l}3.280 \mathrm{E}+02 \\
7.700 \mathrm{E}-05 \\
2.600 \mathrm{E}-03 \\
3.100 \mathrm{E}-02 \\
6.100 \mathrm{E}+05 \\
1.100 \mathrm{E}+06 \\
6.900 \mathrm{E}+07 \\
6.900 \mathrm{E}+07 \\
2.810 \mathrm{E}-01 \\
1.250 \mathrm{E}+07 \\
1.430 \mathrm{E}-02 \\
1.430 \mathrm{E}-02 \\
0.000 \mathrm{E}+00 \\
0.000 \mathrm{E}+00 \\
0.000 \mathrm{E}+00 \\
1.800 \mathrm{E}+05 \\
6.337 \mathrm{E}+03 \\
3.119 \mathrm{E}-03 \\
2.763 \mathrm{E}-02 \\
8.738 \mathrm{E}-03 \\
1.000 \mathrm{E}-01 \\
7.410 \mathrm{E}-04\end{array}$ \\
\hline
\end{tabular}

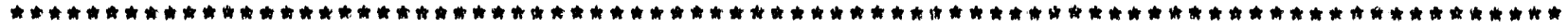

Toxicity Type it Radionuclide carcinogenie inhalation and ingestion

Toxicity Type 2: Chemical carcinogenic Inhalation and ingertion

Toxicity Type 3 , Chemical carcinogenic inhalation, non-carcinogentc ingestion Toxicity Type : Chemical non-carcinogenic inhalation, carcinogenic ingestion roxiclty Type 5: Chemical non-carcinogenic inhalation and lngestion

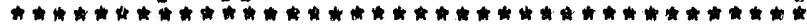

KEY for constituent rable

Constituent $\quad$ a CRSIUM-137+D

Conetituent 2 MERCURY

Constituent $3=$ PCBE (GENERAL) 
Example HPI Output File

USAGL LOCATIOW DATA FOR SURFACE WATER PATHWAY

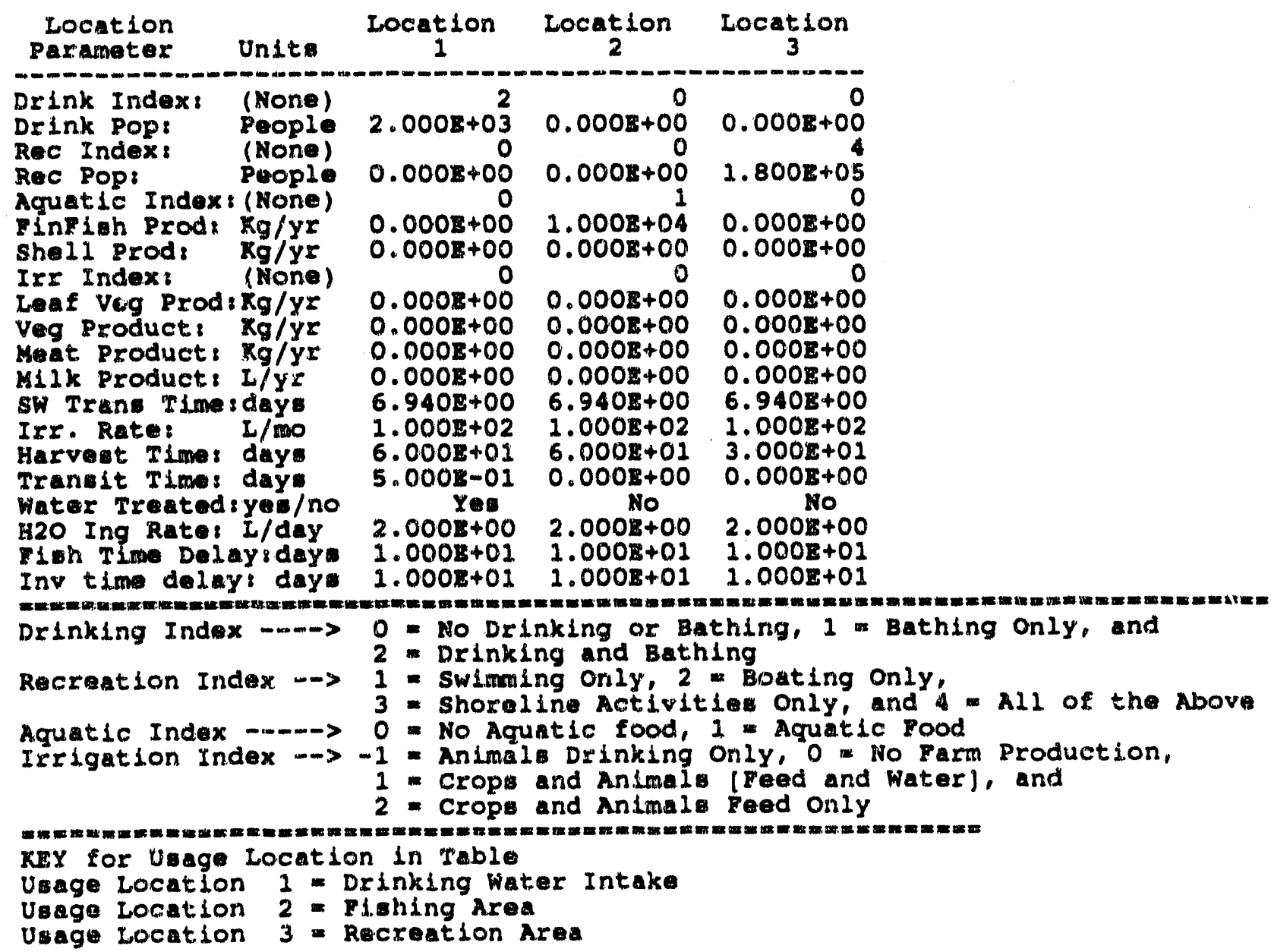




\section{Example HPI Output File}

HPI Values by Usage Location for the SURFACE WATER Trangport Pathway

\begin{tabular}{|c|c|c|c|}
\hline Uaage Location & 1 & ${ }_{2}^{t \text { tuent }}$ & 3 \\
\hline $\begin{array}{l}\text { Drinking Water Intake } \\
\text { Fiohing Area } \\
\text { Recreation Area }\end{array}$ & $\begin{array}{l}23.34 \\
35.13 \\
37.71\end{array}$ & $\begin{array}{r}-20.78 \\
13.57 \\
-26.07\end{array}$ & $\begin{array}{r}7.22 \\
48.12 \\
14.26\end{array}$ \\
\hline Total for Constituent & 39.72 & 13.58 & 48.12 \\
\hline
\end{tabular}


33

Erample HPI Output File

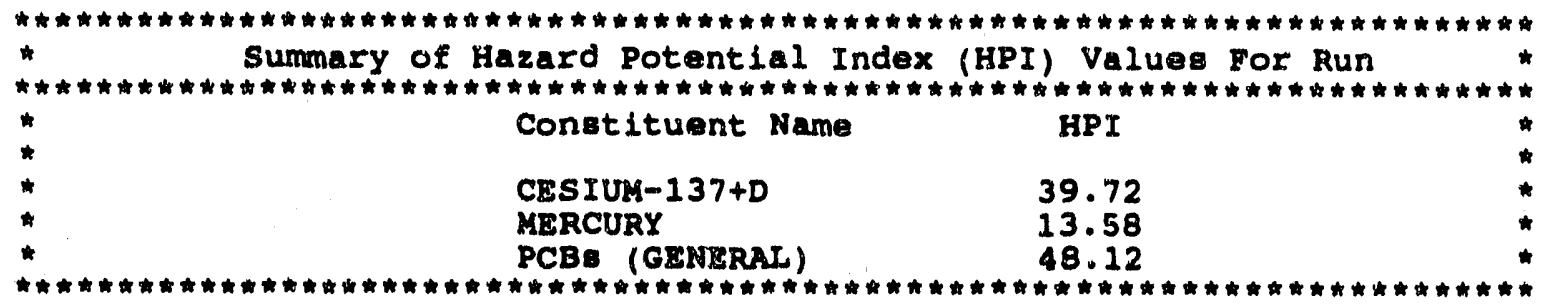




\section{Example HPI Output File}

Maximum Individial Risk Values/RfD Ratios

Exposure Rovise

INGESTION/DERMAI. Drinking Water Finfiah Shellfioh Leafy Vegetablea Other Vegetables Mat.

Mi1k

Swimming

Soil Ingeetion

Special roode

$\begin{array}{cc}\text { [CESIUs-137+D } & \text { Non-Time } \\ \text { Meighted } & \text { Neighted }\end{array}$

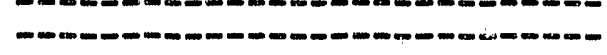

Riok Time Rigk Time Value Per. Value Per.

$1.08 \mathrm{E}-07 \quad 1$ 1.088-07 1

$1.08 \mathrm{E}-07$

$7.748-07$

$0.00 \mathrm{E}+00$

$0.002+00$

$\begin{array}{ll}1 & 1.082-07 \\ 1 & 7.745-07\end{array}$

0 o. $00 \mathrm{~B}+00$

$0.00 \mathrm{~s}+00$

$0.008+00$

$0.00 \mathrm{~B}+00$

$2.24 \mathrm{E}-10$

$0.00 \mathrm{z}+00$

$0.00 \mathrm{D}+00$

0 0.00E+00

$0 \quad 0.00 \mathrm{E}+00$

0 0.00E+00

$0.008+00$

$12.24 \mathrm{E}-10$

$0 \quad 0.00 \mathrm{~s}+00$

$\begin{array}{ll}0 & 0.00 \mathrm{~B}+00 \\ 0 & 0.00 \mathrm{~B}+00\end{array}$

1
1
0
0
0
0
0
1
0
0

[MERCURY
Weighted

RED TIme RFD TIme Ratio Per. Ratio Per.

$4.18 \mathrm{E}-06 \quad 1 \quad 4.18 \mathrm{E}-06$

$4.18 \mathrm{E}-06 \quad 1 \quad 4.18 \mathrm{BE}-06$

$5.41 \mathrm{E}-03 \quad 1 \quad 5.41 \mathrm{E}-03$

$0.00 \mathrm{E}+00$ O $0.00 \mathrm{E}+00$

$0.00 \mathrm{E}+00$ O $0.00 \mathrm{E}+00$

$0.00 \mathrm{E}+00$ O $0.00 \mathrm{z}+00$

$0.00 \mathrm{E}+00$ O $0.00 \mathrm{E}+00$

$0.00 \mathrm{E}+00$ O $0.00 \mathrm{E}+00$

$1.37 \mathrm{E}-08 \quad 1 \quad 1.37 \mathrm{~B}-08$

$0.00 \mathrm{E}+00$ 0 $0.00 \mathrm{z}+00$

$0.00 \mathrm{E}+00$ O $0.00 \mathrm{E}+00$

\begin{tabular}{cccc} 
Rigk & Time & Rigk & Time \\
Value & Pex. & Value & Per. \\
\hline $0.00 \mathrm{~B}+00$ & 0 & $0.00 \mathrm{O}+00$ & 0 \\
$0.00 \mathrm{D}+00$ & 0 & $0.00 \mathrm{O}+00$ & 0
\end{tabular}

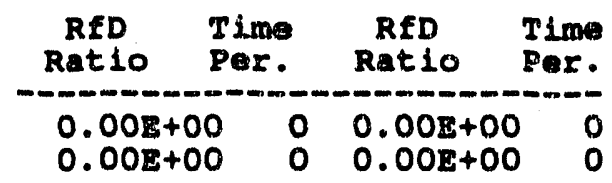

Inhalation

showering

$\begin{array}{lllll} & \begin{array}{l}\text { Risk } \\ \text { Value }\end{array} & \text { Time } & \text { Rigk } & \text { Time } \\ \text { EXTERNAL RADIATION } & \text { Value } & \text { Per. } \\ \text { Boating } & 1.36 \mathrm{E}-11 & 1 & 1.36 \mathrm{E}-11 & 1 \\ \text { Shoreline } & 3.25 \mathrm{E}-08 & 1 & 3.25 \mathrm{E}-08 & 1 \\ \text { Ground } & 0.00 \mathrm{E}+00 & 0 & 0.00 \mathrm{E}+00 & 0\end{array}$

\begin{tabular}{llll} 
Ribk & Time & Risk & Time \\
Value Fer. & Value & Per. \\
\hline $0.00 \mathrm{E}+00$ & 0 & $0.00 \mathrm{E}+00$ & 0 \\
$0.0 \mathrm{OE}+00$ & 0 & $0.00 \mathrm{O}+00$ & 0 \\
$0.00 \mathrm{O}+00$ & 0 & $0.00 \mathrm{E}+00$ & 0
\end{tabular}

For radionuclides and carcinogenic chemicals, RISK VALUEs are used For non-carcinogenic chemicals, RED VALUES are used [dose/RED] 
Example HPI Output File

Maximum Individial Rigk Values/RED Ratios (Cont)

Exposure Route

[PCBs (GENERAL)
Weighted

INGESTION/DERMAL Drinking Water Linfiah Shallf1eh Leafy Vegetables Other Vegetables Meat

Milk

Swimming

Soll Ingestion

Special Pooda

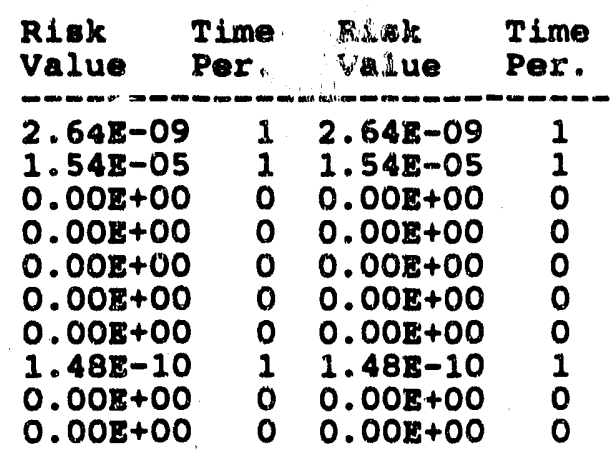

\section{INHALAT ION \\ Inhalation \\ showering}

EXTERNAL RADIATION
Boating
Shoreline
Ground

\begin{tabular}{llcc} 
Rigk & Time & Risk & Time \\
Value & Per. & Value & Per. \\
\hline $0.00 \mathrm{~B}+00$ & 0 & $0.00 \mathrm{~B}+00$ & 0 \\
$0.00 \mathrm{O}+00$ & 0 & $0.00 \mathrm{O}+00$ & 0
\end{tabular}

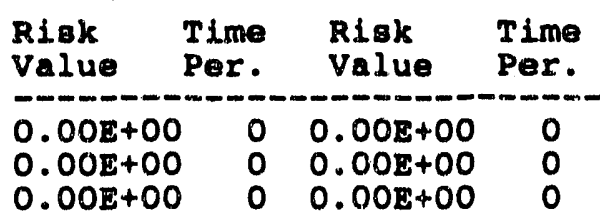

For radionuclides and carcinogenic chemicals, RISK VALUES are uBed For non-carcinogenic chemicals, RfD VALUEs are used [dobe/hfD] 
Example HPI Output File

File Title Summary For Run

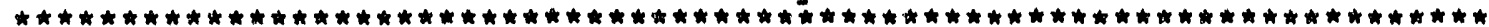

Run Title: Example Ranking Unit --- EXAMPLE .HIN

Run Date and Time: 4/14/1992 16: 2:52

Constituent Database: UPDATED AUGUST 16, 1991

Water Data File: Exampl --- EXAMPLE . WAT 
Appendix C

EXAMPLE WAT OUTPUT FILE 
Example WAT Output File

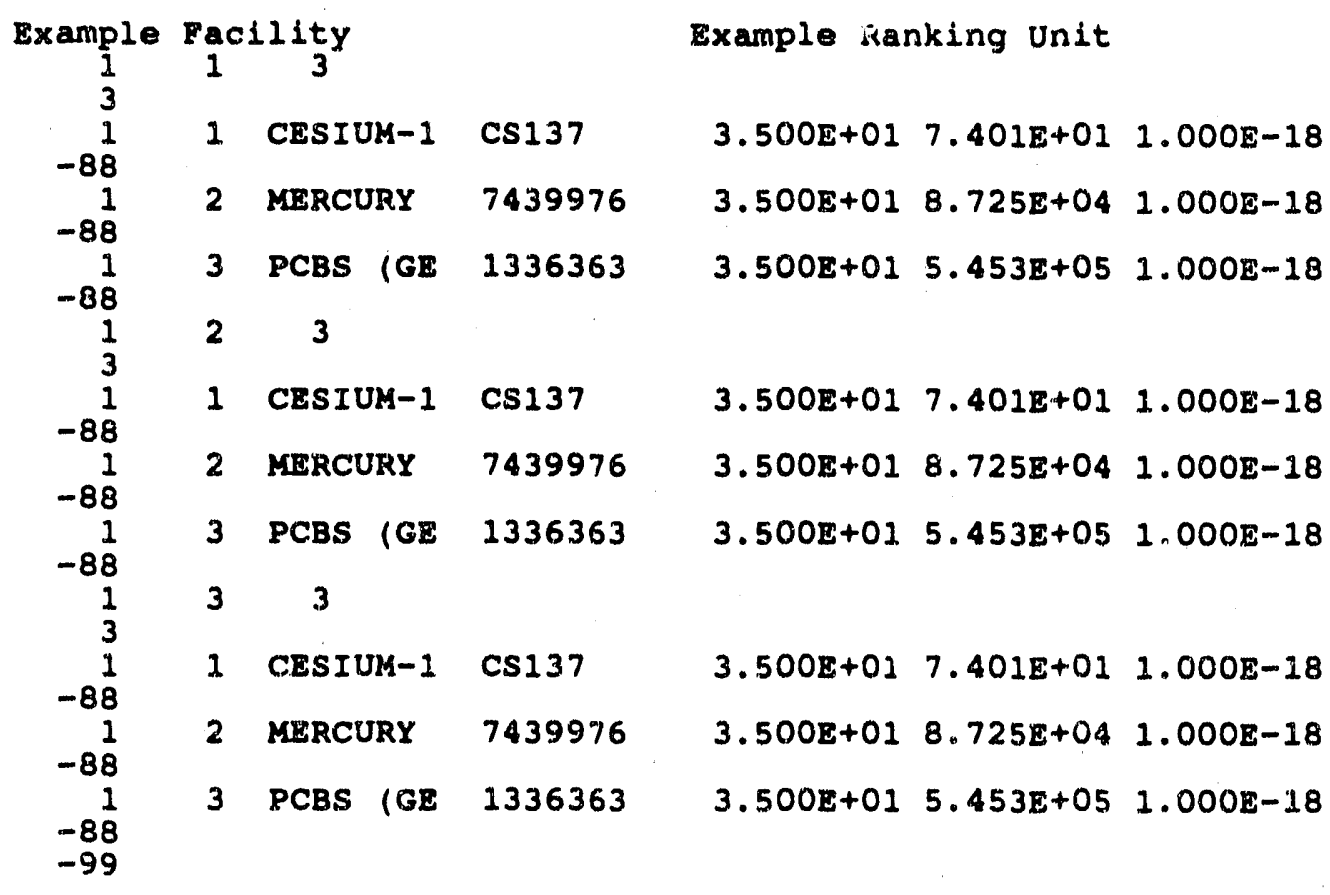


ES/ER/TM-14

\section{DISTRIBUTTION}

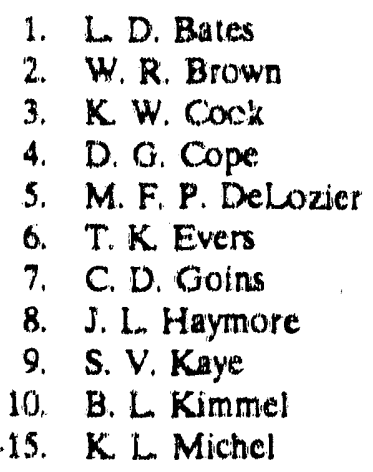

\author{
16. P. T. Owen \\ 17. G. E. Rymer \\ 18. R. H. Snyder \\ 19. D. W. Swindle \\ 20. C. C. Travis \\ 21. R. K. White \\ 22. G. E. Whitesides \\ 23. Ceniral Research Library \\ 24-26. Environmental Sciences Library \\ 27-31. ER Document Managament Center \\ 32. ORNL Luboratory Records
}

33. P. H. Edmonds, Radian Corporation, 120 South Jefferson Circle, Oak Ridge, TN 37830

34-37. W. E. Murohie, DOE, Office of Environmental Resioration, Eastern Area D\&D Branch, EM. 423 (GTN), Washington, DC 20545

38-39. R. C. Sleeman, DOE Oak Ridge Field Office, P.O. Box 2001, Oak Ridge, TN 37831-8541

40. S. P. Riddle, DOE Oak Ridge Field Office, P.O. Box 2001, Oak Ridge, TN 37831-8541

41. C. S. Gist, DOE Oak Ridge Field Oftice, P.O. Box 2001, Oak Ridge, TN 37831.8541

42. W. N. Lingle, DOE Oak Ridge Field Office, P.O. Box 2001, Oak Ridge, TN 37831-8541

43. S. L. Lankford, DOE Oak Ridge Field Office, P.O. Box 2001, Oak Ridge, TN 37831.8541

44. A. T, Manion, DOE Oak Ridge Field Office, P.O. Box 2001, Oak Ridge, TN 37831-8541

45. D. G. Page, DOE Oak Ridge Field Office, P.O. Box 2001, Oak Ridge, TN 37831-8541

46. M. A Travaglini, DOE Oak Ridge Field Office, P.O. Box 2001, Oak Ridge, TN 37831-8541

47. A. B. Perkins, DOE Oak Ridge Field Office, P.O. Box 2001, Oak Ridge, "TN 37831-8541

48. D. W. Dollins, DOE Oak Ridge Fleld Office, Bld\&. XT-801, Piketon, OH 45661

49. R. C. Edwards, DOE Oak Ringe Field Office, Bldg. C-100, Paducah, KY 42001

50. T. Longo, DOE, 12800 Middlebrook Road, Trevion 2 Building, Germantown, MD 20374

51. F. Baxter, DOE, 12800 Middlebrook Road, Trevion 2 Building, Germantown, MD 20874

52. G. P. Turi, DOE, 12800 Middlebrook Road, Trevion Building, Germantown, MD 20874

53. R. J. AJken, DOE, 1000 Independence Avenue, Suite GE045, Washington, DC 201585

54. Jack Craig, DOE Fernald Field Office, P.O. Box 398705, Cincinnati, Ohio 45239. \$705

55. W. W. Tolbert, Science Applications International Corporation, 301 laboratory Road, Oak Ridge, TN 3783)

56. Ken Duke, Science Applications international Corporation, 301 laboratory Road, Oak Ridge, TN 37830

57. Sue Peterman. Wertinghouse Materials Company of Ohio, 7400 Willey Road, Fermald, Ohio 45030

58-59. J. Droppo, Battelle Pacifa- Northwest Laboratories, Battlle Boulevard, P. D. Box 999, K6-76, Richland, WA 99352

60. A. Toblin, Halliburton NUS Erivironmental Corporation, 910 Clipper Road, Gaithersburg, MD 208877

OFFICE OF ASSISTANT MANAGER. ENERGY RESEARCH AND DEVELOPMENT, U.S. DEPARTMENT OF ENERGY, DOE FIELD OFFICE, OAK RIDGE. POST OFFICE BOX 2(\$11. OAK RIDGE. TN 37831.8690)

OFFICE OF SCIENTIFIC AND TECHNICAL INFORMATION, PO. BOX 62.

OAK RIDGE. TN 37831 

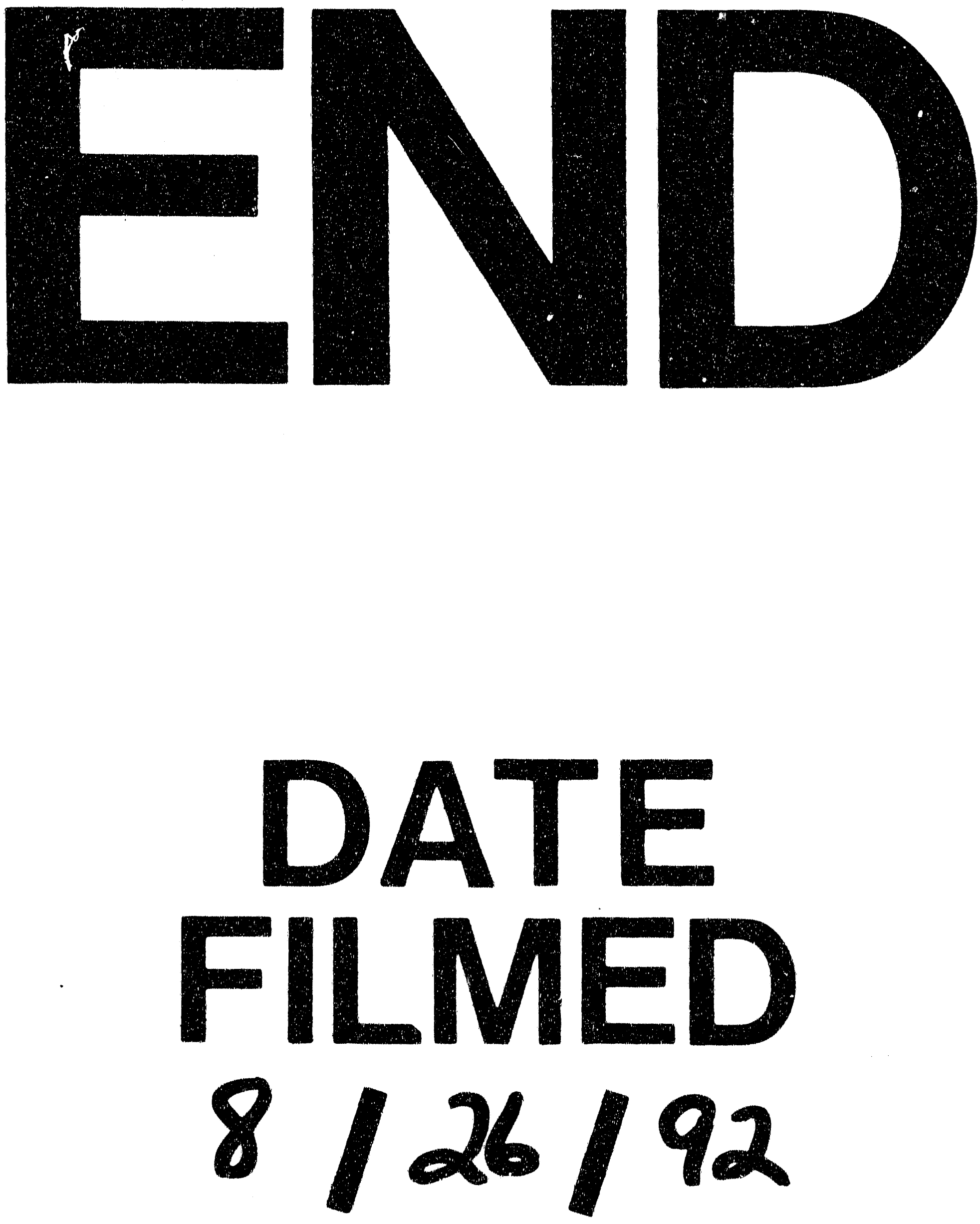


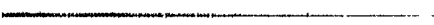

